\title{
MALACOFAUNA OF THE UPPER HOLOCENE RIVER DEPOSITS IN KORYTNICA (S POLAND)
}

\author{
Witold PAWE⿺ AleXANDROWICZ
}

\begin{abstract}
Chair of Stratigraphy and Regional Geology, Academy of Mining and Metallurgy, Mickiewicza 30, 30-059 Kraków, Poland

ABSTRACT: Rich and diverse mollusc assemblages occur in Upper Holocene sand and mud developed near Korytnica in the southern margin of the Świętokrzyskie Mts. Four profiles of these sediments have been found in the valley of a small stream, ca. 1-1.5 km W of the village centre. Three types of assemblages can be distinguished. The first, occurring in alluvial deposits forming the lower terrace of the stream, has a considerable proportion of land snails, especially woodland species. The second corresponds with the development of a small fish-pond, in existence since the 19th c. till World War II, and is dominated by water molluscs. The third malacocenosis is associated with the last phase of filling, overgrowing and drainage of the fish-pond. Open-country, mesophile and higrophile species are its main components. The succession of mollusc assemblages indicates changes of palaeogeographic conditions during the last phase of the Holocene controlled mainly by human impact.
\end{abstract}

KEY WORDS: mollusc assemblages, fluviatile deposits, environmental changes, Upper Holocene, Nida Basin

\section{INTRODUCTION}

The studied area is situated ca. $20 \mathrm{~km} \mathrm{~N}$ of Pińczów, in the northern part of the Nida Basin, between the villages Korytnica and Karsy (Fig. 1). The geological structure of the region was described by RADWAŃSKI (1969, 1973), KUTEK \& GŁAZEK (1972), BAŁUK \& RADWAŃSKI (1977) and many others. Two main geological formations can be distinguished. One consists of limestones of Upper Jurassic age, building the hills that surround basins filled by littoral deposits of Miocene age. The other comprises a sedimentary sequence composed of the world-famous fossiliferous Korytnica Clays, overlain by marls and lithothamnian limestones. These deposits, especially the Korytnica Clays, contain very rich and diverse fossil assemblages. Quaternary deposits are developed as alluvial or fluvioglacial gravels, sand and mud, as well as loesses (LINDNER 1977).

Upper Holocene sediments abounding with mollusc shells have been found in the mid part of the valley of a small stream between the villages Korytnica and Karsy. East of the centre of Korytnica the valley is relatively narrow. The stream passes between two hills composed of Upper Jurassic limestones and forms a small ravine. In its uppermost part the valley becomes wide (Fig. 1). From the first half of the 19th c. till the end of World War II a small fish pond existed in this zone. Fragments of the dam are still well visible (Fig. 1).

Four profiles of sediments containing mollusc shells have been found and documented during fieldwork (Kt-I - Kt-IV) (Fig. 1). Profile Kt-I is situated in the upper, marginal part of the ancient pond. Seven lithological components can be distinguished from the bottom upwards: grey mud with fragments of marls and limestones of Miocene age $(1.3-1.5 \mathrm{~m})$, grey mud (1.05-1.3 m), dark mud with plant remains $(0.90-1.05 \mathrm{~m})$, yellow sand $(0.60-0.90 \mathrm{~m})$, grey mud $(0.30-0.60 \mathrm{~m})$, yellow sand $(0.15-0.30 \mathrm{~m})$ and recent soil $(0.15-0.00 \mathrm{~m})$ (Fig. $2 \mathrm{Pr}$ ). The sediments correspond with the lower terrace of the stream. The intercalations of mud can be associated with the distal part of the pond. Profiles Kt-II, Kt-III and Kt-IV are developed as grey and dark mud, representing sediments filling up the pond, underlain by yellow sand forming the lower terrace of the stream and covered by recent soil. The thickness of these deposits varies from $1.0 \mathrm{~m}$ (Kt-II) to $1.5 \mathrm{~m}$ (Kt-III and Kt-IV) (Figs 2 Pr, 3 Pr). 


\section{MATERIAL AND METHODS}

Twenty-six samples of mollusc-bearing deposits were collected from the profiles described above. The samples were washed in order to extract all the mollusc shells or their fragments that could be determined. The whole material comprises 43 species of land snails, 16 taxa of aquatic snails and 8 of bivalves represented by 7,601 specimens. The species have been assigned to ecological groups proposed by LOŽEK (1964) and S. W. ALEXANDROWICZ (1987a). Five groups have been distinguished in the malacological spectra of specimens (MSI): shade-loving snails, open-country species, mesophile snails living in both shady and open habitats of varied humidity, higrophile taxa inhabiting wet meadows as well as swamps and marshes, and water molluscs. The changes of mollusc assemblages are illustrated on two-component and triangular diagrams. Relations among particular indices as well as ecological valency of species described by PIECHOCKI (1979), RIEDEL (1988) and PIECHOCKI \& DYDUCH-FALNIOWSKA (1993) were applied in the ecological and stratigraphical interpretation.

\section{RESULTS}

Profile Kt-I is situated in the eastern, marginal part of the ancient pond. It contains deposits filling the pond as well as sediments forming the low terrace of the stream (Fig. 1, 2 Pr). Eight samples (Kt-1 - Kt-8) rich in mollusc shells have been collected (Fig. $2 \mathrm{Sa}$ ). The number of taxa per sample varies from 8 to 23 , while the number of specimens is 13-186 (Fig. $2 \mathrm{~N}$ ). Woodland snails, represented by single shells of Perforatella bidentata (Gmel.), Discus rotundatus (O. F. Müll.) and a few other taxa, occur in the lower and upper part of the sequence (Fig. 2 M, Table 1). Open-country species are an important component of the described fauna. Numerous specimens of Vallonia pulchella (O. F. Müll.) and Pupilla muscorum (L.) have been found. The occurrence of xerophile snails, such as Truncatellina costulata (Nilss.) and Helicopsis striata (O. F. Müll.), in the uppermost part of profile Kt-I is nothewothy. Mesophile taxa are a subordinate component of this fauna. Higrophile species, such as Carychium minimum O. F. Müll. and Succinea putris (L.), are common in the whole profile (Fig. 2 M, Table 1). Water molluscs are principal components of this assemblage. The occurrence of snails inhabiting shallow, temporary water bodies (Lymnaea truncatula (O. F. Müll.) and Anisus leucostomus (Mill.)), accompanied by taxa living in permanent small lakes or ponds with rich vegetation (Valvata cristata O. F. Müll. Gyraulus laevis (Ald.)), as well as species typical of flowing water (Pisidium nitidum

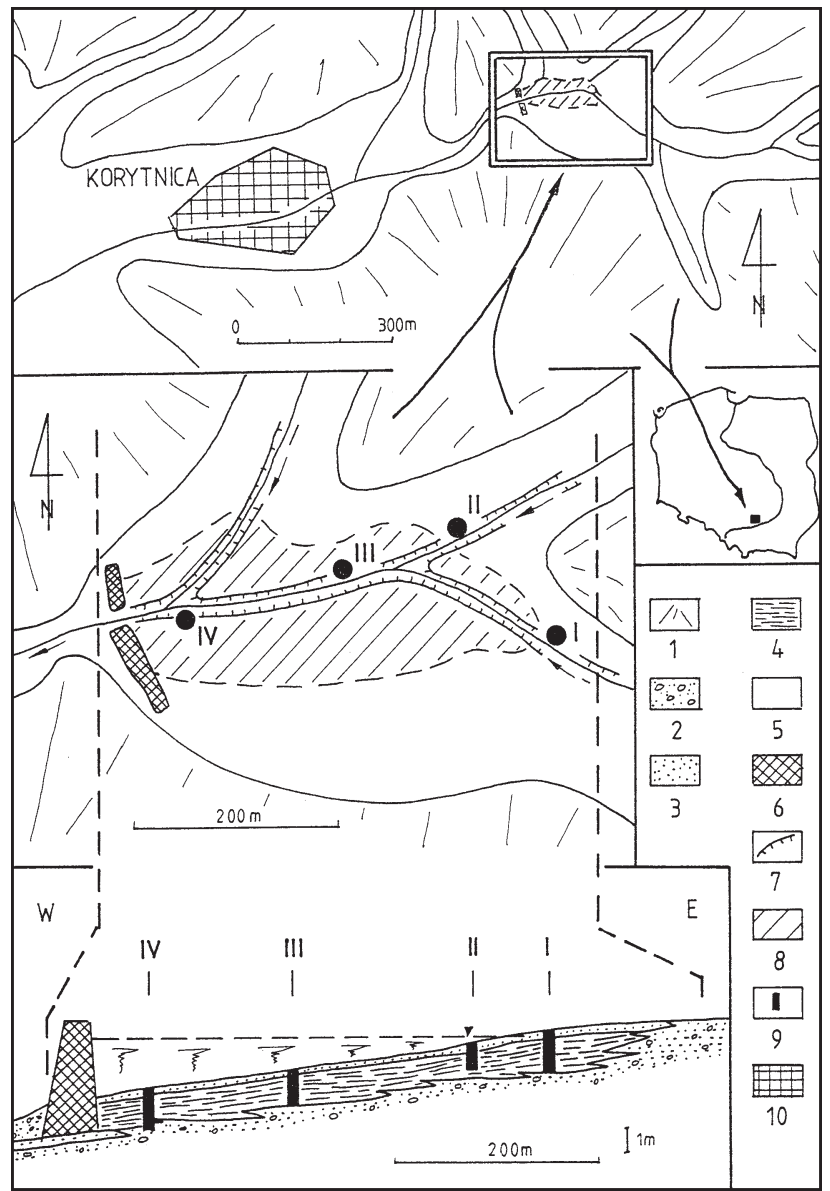

Fig. 1. Location of profiles of Upper Holocene deposits near Korytnica: 1 - slopes, 2 - sand with gravel, 3 - sand, 4 mud, 5 - valley bottom, 6 - village, 7 - terrace risers, 8 fish pond, 9 - profiles (I-IV), 10 - dam

Jenyns, $P$. personatum Malm and $P$. subtruncatum Malm), has been noted (Fig. 2 M, Table 1).

Habitat changes are reflected in the two-component diagrams (Fig. 2 D). The first one (D-1) shows the relationships between land snails (L; ecological groups 1-9) and water molluscs (W; ecological groups 10-12). Two intervals with the dominance of water molluscs can be distinguished, corresponding to periods of the maximum size of the pond (samples: Kt-2, Kt-3, Kt-5). The second diagram (Fig. 2 D: D-2) illustrates relations between species inhabiting swamps, marshes as well as temporary water bodies and molluscs living in permanent stagnant waters or typical for rivers and streams. The former component prevails in the mid part of the profile. The last diagram reflects relations between stagnant and moving water species (Fig. 2 D: D-3). Three intervals dominated by molluscs typical of rivers and streams can be distinguished. They correspond to periods of minimum size of the pond (samples: Kt-1, Kt-4, Kt-8).

Profile Kt-II is situated in the north-eastern marginal zone of the ancient pond (Fig. 1). Four samples containing mollusc shells (Kt-9 - Kt-12) have been collected (Fig. $2 \mathrm{Sa}$ ). The number of taxa varies from 


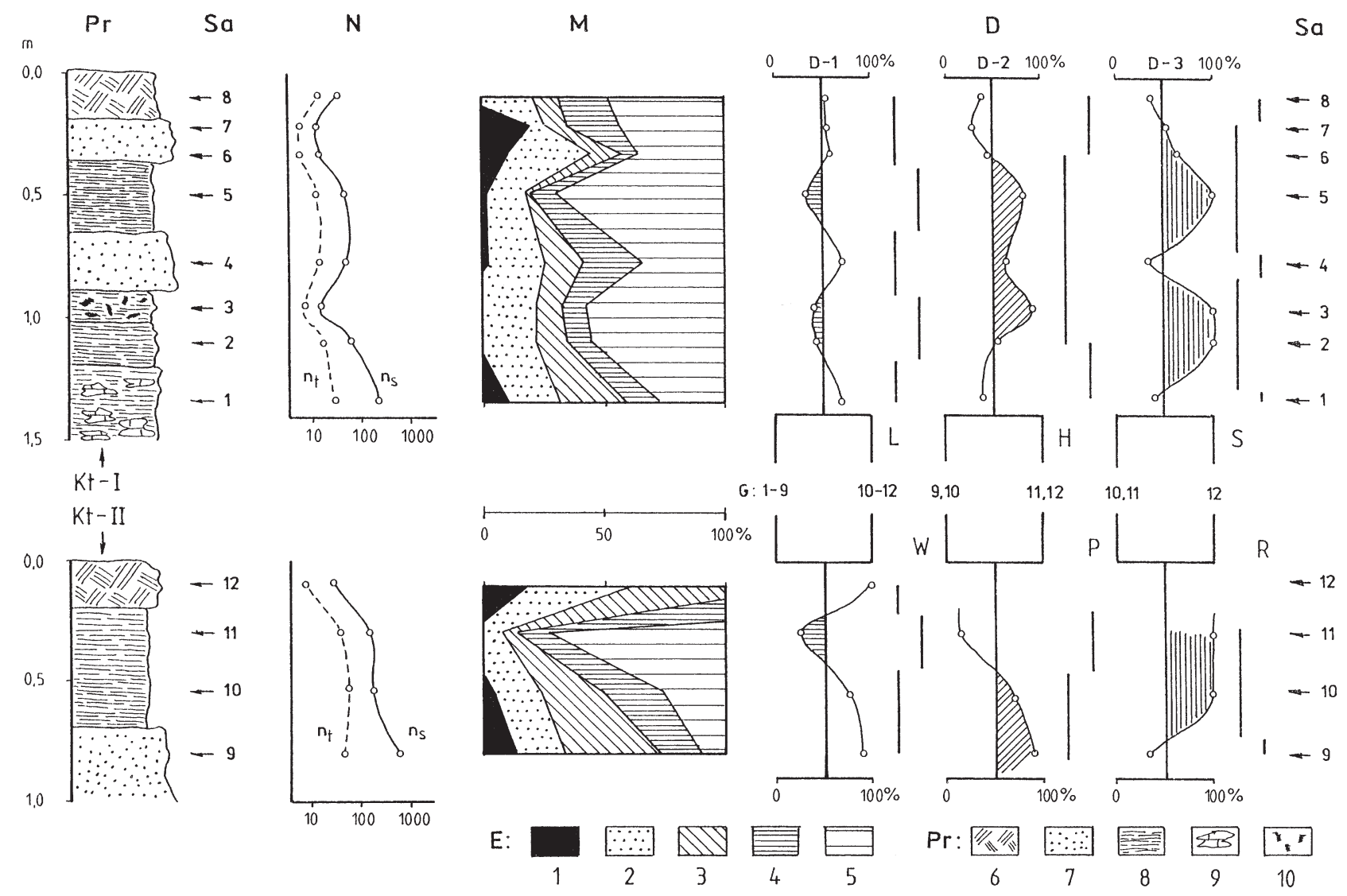

Fig. 2. Lithology and malacofauna of profiles Kt-I and Kt-II: E - ecological groups of molluscs (based on LOŽEK 1964 and S.W. ALEXANDROWICZ 1987a): 1 - shade-loving species, 2 - open-country species, 3 - mesophile species, 4 - higrophile species, 5 - water species; $\operatorname{Pr}$ - lithology: 6 - recent soil, 7 - sand, 8 - mud, 9 - fragments of Cretaceous marls, 10 - plant remains; Sa - samples, $\mathrm{N}$ - number of taxa $\left(\mathrm{n}_{\mathrm{t}}\right)$ and number of specimens $\left(\mathrm{n}_{\mathrm{s}}\right), \mathrm{M}$ - malacological spectrum of individuals (MSI), $\mathrm{D}$ - two-component diagrams, $\mathrm{L}$ - land snails, $\mathrm{W}$ - water molluscs, $\mathrm{H}$ - higrophile snails and molluscs of temporary water bodies, $\mathrm{P}$ - molluscs living in permanent water bodies and in moving water, $\mathrm{S}$ - molluscs of stagnant waters, $\mathrm{R}$ - mollucsc of moving waters, G - ecological groups (based on LOŽEK 1964 and S.W. ALEXANDROWICZ 1987a): 1-9 - land snails, 10 - molluscs of temporary water bodies, 11 - molluscs of permanent water bodies, 12 - molluscs of flowing water

7 to 46 , and the number of specimens from 26 to 666 (Fig. $2 \mathrm{~N}$ ). Woodland snails are common in the lower and upper part of the sequence. They are represented both by forest-dwelling species (Acicula polita (Hartm.), Ruthenica filograna (Rossm.), Discus rotundatus (O. F. Müll.), Bradybaena fruticum (O. F. Müll.)) and snails typical of wet, shady habitats (Perforatella bidentata (Gmel.)). Open-country taxa (Vallonia pulchella (O. F. Müll.), V. costata (O. F. Müll.), Pupilla muscorum (L.)) constitute up to $20 \%$ of the assemblage. Mesophile and higrophile species (Cochlicopa lubrica (O. F. Müll.), Carychium tridentatum (Risso), Vertigo angustior Jeffr., Carychium minimum O. F. Müll., Succinea putris (L.)) occur mainly in the lower part of the sequence. Water molluscs are represented by snails of temporary water bodies (Lymnaea truncatula (O. F. Müll.), Anisus leucostomus (Mill.)), accompanied by species of permanent waters, such as Valvata cristata O. F. Müll., Gyraulus laevis (Ald.), G. albus (O. F. Müll.). Bivalves preferring flowing water: Pisidium personatum Malm have been found only in the lowermost part of the profile (Fig. 2 M, Table 1).
The two-component diagram D-1 (Fig. 2 D) illustrates the dominance of water molluscs only in sample Kt-11. It corresponds with the phase of maximum size of the pond. The transformation of the pond into a swamp or even wet meadow is presented in diagram D-2, while diagram D-3 indicates an important influence of the stream in the lowermost part of the sequence.

Profile Kt-III derives from the central part of the pond (Fig. 1). Seven samples (Kt-13 - Kt-19) (Fig. 3 $\mathrm{Sa})$ contained rich mollusc assemblages. The number of taxa is 16-42, and number of specimens 125-1,071 (Fig. $3 \mathrm{~N})$. The proportion of shade-loving (Perforatella bidentata (Gmel.)), open-country (Vallonia pulchella (O. F. Müll.), V. costata (O. F. Müll.)) and mesophile snails (Cochlicopa lubrica (O. F. Müll.), Carychium tridentatum (Risso), Succinea oblonga Drap.) is limited. Taxa typical of humid habitats (Carychium minimum O. F. Müll., Succinea putris (L.), Perforatella rubiginosa (A.Schm.) are an important component of the assemblage. Land snails occur frequently in the lower and upper part of the profile (Fig. $3 \mathrm{M}$ ). Water 
Table 1. Malacofauna of the Upper Holocene sediments from Korytnica: E - ecological groups (based on LOŽEK 1964 and S. W. AlEXANDROWICZ 1987a); 1 - typical forest species, 2 - species inhabiting mainly forests, 3 - species of moist forests, 4 - xerophile species, 5 - open-country species, 6 - mesophile species of dry habitats, 7 - mesophile species of moderately humid habitats, 8 - mesophile species of humid habitats, 9 - higrophile species, 10 - molluscs of temporary water bodies, 11 - molluscs of permanent water bodies, 12 - mollucsc of flowing water; number of specimens (based on S. W. AleXANDrowicZ 1987a): 1. 1-3, 2. 4-10, 3. 11-32, 4. 33-100, 5. 100-316

\begin{tabular}{|c|c|c|c|c|c|c|c|c|c|c|c|c|c|c|c|c|c|c|c|c|c|c|c|c|c|c|c|}
\hline \multirow{2}{*}{$\mathrm{E}$} & TAYOY & & & $\mathrm{KOR}$ & TTN & CA & $\mathrm{KT}$ - & & & & KT & - II & & & $\mathrm{KO}$ & RYTI & NICA & $\mathrm{KT}$ & - III & & & $\mathrm{KO}$ & RYTI & NICA & A KT & - IV & \\
\hline & 1AXUN & 1 & 2 & 3 & 4 & 5 & 6 & 7 & 8 & 9 & 10 & 11 & 12 & 13 & 14 & 15 & 16 & 17 & 18 & 19 & 20 & 21 & 22 & 23 & 24 & 25 & 26 \\
\hline 1 & Acicula polita & 1 & & & & & & & & 3 & 1 & & & 3 & 1 & & 1 & & & & & & & & & & \\
\hline 1 & Vertigo pusilla & 1 & & & & & & & & & & & & 1 & & & & & & & & & & & & & \\
\hline 1 & Ena obscura & & & & & & & & & & & & & 1 & & & & & & & & & & & & & \\
\hline 1 & Aegopinella pura & & 1 & & & & & & & 1 & & & & & & & & & & & & & & & & & \\
\hline 1 & Cochlodina orthostoma & & & & & & & & & 1 & & & & & & & & & & & & & & & & & \\
\hline 1 & Cochlodina laminata & & & & & & & & & 2 & & & & 1 & & & & & & & & & & & & & \\
\hline 1 & Ruthenica filograna & & & & & & & & & 3 & & & & 3 & & & & & & & & & & & & & \\
\hline 2 & Discus rotundatus & 1 & & & & 1 & & & & 2 & & & & 1 & 1 & & & & & & & & & & & & \\
\hline 2 & Vitrea crystallina & & & & & & & & & 1 & 1 & & & & 1 & & & & & & & & & & & & 1 \\
\hline 2 & Alinda biplicata & & & & & & & & & 1 & & & & 2 & & & & & & & & & & & & & \\
\hline 2 & Bradybaena fruticum & 1 & & & & & & & & 3 & 1 & & & 3 & 1 & & & & & & & & & & & & \\
\hline 2 & Helix pomatia & & & & & & & & & 1 & & & & & & & & & & & & & & & & & \\
\hline 3 & Perforatella umbrosa & & & & & & & & & 1 & & & & 1 & & & & & & & & & & & & & \\
\hline 3 & Perforatella vicina & & & & & & & & & & & & & 1 & 1 & & & & & & & & & & & & \\
\hline 3 & Perforatella bidentata & 2 & & & 1 & & 1 & 1 & & 3 & 1 & & 2 & 3 & 2 & & & & & 1 & & & & & & & \\
\hline 4 & Truncatellina costulata & & & & & & & & 1 & 1 & & & & & & & & & & & & & & & & & \\
\hline 4 & Helicopsis striata & & & & & & & & 1 & & & & & & & & & & & & & & & & & & \\
\hline 5 & Vertigo pygmaea & & & & 1 & & 1 & & & 1 & & 1 & & 1 & & & & & 1 & & & & & & 1 & & 1 \\
\hline 5 & Pupilla muscorum & 3 & 2 & & 1 & & & & 1 & 2 & 2 & 1 & 1 & 3 & 2 & & & 1 & & 1 & 1 & & 1 & 1 & 1 & 2 & 1 \\
\hline 5 & Vallonia costata & 2 & & & & & 1 & & & 3 & 2 & & 1 & 3 & 2 & & & & 1 & & & & & & & 1 & 3 \\
\hline 5 & Vallonia pulchella & 3 & 3 & 2 & 3 & 2 & 2 & 1 & 2 & 4 & 4 & 3 & 2 & 4 & 3 & 1 & & 1 & 2 & 4 & 1 & 1 & 1 & 3 & 4 & 4 & 5 \\
\hline 5 & Euomphalia strigella & & & & & & & & & 1 & & & & 3 & & & & & & & & & & & & & \\
\hline 6 & Cochlicopa lubricella & & & & & & & & & & 1 & & & & & & & & & & & & & & & & \\
\hline 7 & Cochlicopa lubrica & 1 & 1 & 1 & 1 & 1 & 1 & & & 3 & 2 & & 1 & 3 & 2 & 1 & & & & 1 & & & & & 1 & 1 & 2 \\
\hline 7 & Vertigo alpestris & & & & & & & & & & 1 & & & & & & & & & & & & & & & & \\
\hline 7 & Punctum pygmaeum & & 1 & & & & & & & 2 & 1 & & & 1 & & & & & & & & & & & & 1 & \\
\hline 7 & Vitrina pellucida & & & & & & & & & 1 & & & & & & & & & & & & & & & & & \\
\hline 7 & Nesovitrea hammonis & & 1 & & & & & & & 2 & 1 & & & 2 & 2 & & & & 1 & & & & & & & & 1 \\
\hline 7 & Vitrea contracta & & & & & & & & & & & & & 1 & & & & & & & & & & & & & \\
\hline 7 & Limacidae & & & & & & & & & 1 & 1 & & & 1 & & & & & & & & & & 1 & 1 & 2 & 1 \\
\hline 7 & Euconulus fulvus & 1 & & & & & & & & 1 & & & & & & & & & & & & & & & & & \\
\hline 7 & Clausilia dubia & & & & & & & & & 1 & & & & & & & & & & & & & & & & & \\
\hline 8 & Carychium tridentatum & 3 & 2 & & 1 & & & & & 4 & 4 & 1 & & 4 & 3 & 1 & & & & & 1 & 1 & & 2 & & & 3 \\
\hline 8 & Vertigo angustior & 1 & 1 & 1 & 1 & & & 1 & 1 & 4 & 1 & 2 & 2 & 2 & 1 & & & & & 2 & & & & & 1 & 3 & 3 \\
\hline 8 & Succinea oblonga & 1 & & & 1 & & & & & 3 & 1 & 1 & 2 & 1 & 1 & & 1 & & & 1 & & 1 & & 1 & 1 & & 1 \\
\hline 9 & Carychium minimum & 3 & 1 & & 1 & 1 & & & 1 & 3 & & & & 4 & 3 & & & & 1 & 1 & 1 & & & & 2 & 3 & 2 \\
\hline 9 & Vertigo antivertigo & & 1 & 1 & & & & & & 2 & 1 & 1 & & & 1 & 1 & & 2 & 3 & & & 1 & 1 & & 3 & 3 & 1 \\
\hline 9 & Vertigo moulinsiana & & & & & & & & & 1 & & & & & & & & & & & & & & 1 & & & \\
\hline 9 & Vallonia eniensis & & & & & & & & & 1 & & 1 & & 1 & & & & & 1 & & & & & & & & 3 \\
\hline 9 & Succinea putris & 2 & 1 & 1 & 3 & 1 & 1 & 1 & 1 & 4 & 3 & 3 & & 4 & 2 & 3 & 3 & 4 & 4 & 4 & 2 & 3 & 4 & 4 & 4 & 4 & 4 \\
\hline 9 & Succinea elegans & & & & & & & & & & & & & & & & & 3 & & & & & & & & & \\
\hline 9 & Zonitoides nitidus & 2 & & & & & & & & & & & & 1 & 1 & & & & & 1 & & & & & & 1 & 2 \\
\hline 9 & Perforatella rubiginosa & 1 & 1 & & 1 & & & & & 2 & 1 & 1 & & 3 & 1 & & & & 2 & 2 & & 1 & & 1 & 3 & 3 & 4 \\
\hline 10 & Valvata pulchella & & & & & & & & & & & 1 & & & & & 1 & 4 & 1 & & & 2 & 3 & 4 & & & \\
\hline 10 & Lymnaea truncatula & 3 & 3 & 2 & 1 & 3 & 1 & & 1 & 3 & 3 & 3 & & 4 & 3 & 2 & 2 & 3 & 2 & 1 & 2 & 1 & 3 & 3 & 3 & 3 & \\
\hline 10 & Anisus leucostomus & 3 & 3 & 2 & 2 & 3 & & & 2 & 3 & 2 & 4 & & 5 & 3 & 5 & 4 & 5 & 4 & & 2 & 4 & 4 & 5 & 5 & 4 & 3 \\
\hline 10 & Segmentina nitida & & & & & & & & & & & 1 & & & 1 & & & 2 & & & & & 2 & 2 & & & \\
\hline 10 & Pisidium obtusale & & & & & & & & & & & 2 & & 1 & & & & 3 & 1 & & & & 2 & 2 & & & \\
\hline 11 & Valvata cristata & 1 & 2 & & 1 & 1 & & 1 & & 3 & 3 & 4 & & & 2 & 1 & & 4 & 4 & 2 & & & 3 & 5 & 5 & 4 & 2 \\
\hline 11 & Valvata piscinalis & & 1 & & & & & & & & & & & & & & & 3 & & 1 & & & 3 & 3 & & 1 & \\
\hline 11 & Bithynia tentaculata & & & 1 & & & & & & 1 & 1 & 2 & & 4 & 1 & & & 3 & 3 & 1 & & 1 & 3 & 4 & 3 & 3 & 1 \\
\hline 11 & Lymnaea stagnalis & & & & & 1 & & & & & & & & & & & & 1 & & & & & & 2 & & & \\
\hline 11 & Stagnicola palustris & & 1 & & & & & & & 1 & 1 & 2 & & 1 & & 1 & & 4 & 3 & 1 & & 3 & 3 & 4 & 4 & 3 & 2 \\
\hline 11 & Lymnaea peregra & 1 & 1 & & & 1 & & & 1 & & 1 & & & 4 & 1 & 1 & 1 & 4 & 2 & & & 1 & 3 & 2 & 1 & 1 & 1 \\
\hline 11 & Lymnaea auricularia & & & & & & & & & & & & & & & & & & & & & & 1 & & & & \\
\hline 11 & Anisus contortus & & 1 & & & & & & & 1 & 1 & 1 & & 1 & & & 2 & 5 & 1 & & & 3 & 5 & 4 & 3 & 3 & \\
\hline 11 & Gyraulus albus & & & & 1 & & & & 1 & 1 & 1 & 2 & & 3 & 1 & & 2 & 4 & 3 & & & 2 & 4 & 5 & 3 & 2 & \\
\hline 11 & Gyraulus laevis & 2 & 1 & & & & & 1 & & & 2 & 3 & & 4 & 3 & & 2 & 3 & & & & 3 & 3 & 4 & & 1 & \\
\hline 11 & Armiger crista & & 1 & & & & & & & 1 & 2 & 1 & & 2 & 1 & 1 & 1 & 1 & 1 & & & 2 & 1 & 3 & & 1 & \\
\hline 11 & Acroloxus lacustris & & & & & & & & & & & & & & & & & & & & & & & 1 & & & \\
\hline 11 & Anodonta cygnea & & & & & & & & & & & & & & & & & & & & & & & 1 & & & \\
\hline 11 & Pisidium milium & & & & & & & & & 1 & & 2 & & & & 3 & 2 & 3 & 2 & & 2 & 2 & 2 & 3 & 1 & 2 & \\
\hline 11 & Pisidium pseudosphaerium & & & & & & & & & & & & & & & & & 3 & & & & & 2 & 2 & & & \\
\hline 11 & Pisidium subtruncatum & 2 & 2 & & 2 & 1 & & 1 & 1 & 1 & 1 & 2 & & 1 & & 1 & 1 & 3 & 2 & 1 & 1 & 2 & 3 & 3 & 3 & 2 & \\
\hline 11 & Pisidium casertanum & 3 & 2 & & 1 & 1 & 1 & & 2 & 1 & 1 & 2 & & 2 & 1 & 1 & 3 & 4 & 2 & 3 & 1 & 3 & 3 & 4 & 2 & 2 & 2 \\
\hline 12 & Pisidium nitidum & 4 & & & 4 & & 3 & 4 & 2 & & & & & & & & & 1 & & 1 & & & & & & 1 & \\
\hline 12 & Pisidium personatum & 3 & & & 3 & & 2 & 1 & 4 & 4 & & & & & & & & & & & & & & & & & \\
\hline
\end{tabular}




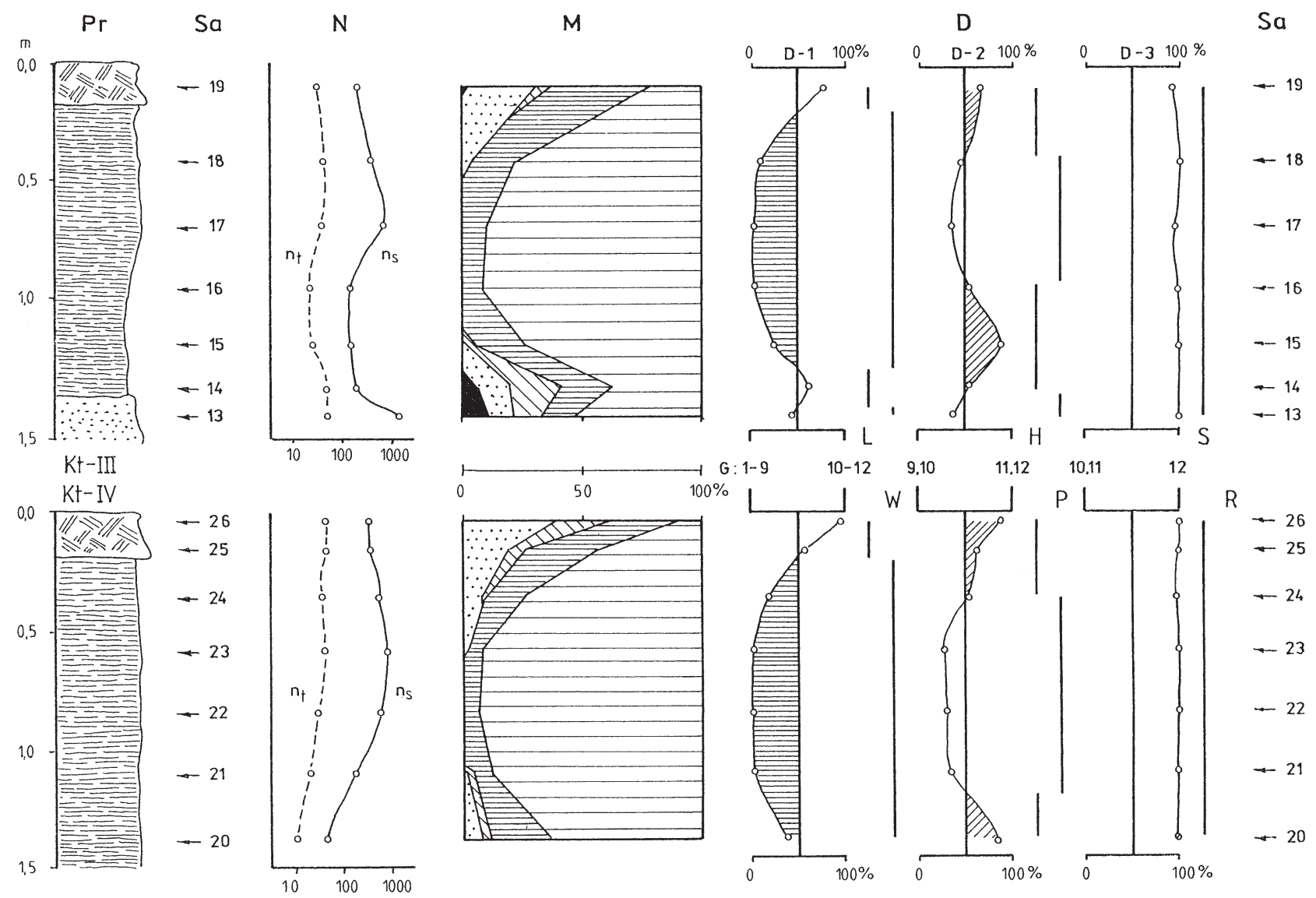

Fig. 3. Lithology and malacofauna of profiles Kt-III and Kt-IV. For explanations see Fig. 2

molluscs dominate in the fauna. Species of temporary water bodies, such as Valvata pulchella Studer, Lymnaea truncatula (O. F. Müll.) and Anisus leucostomus (Mill.), are represented by numerous specimens. Taxa preferring permanent stagnant waters of rich vegetation (Valvata cristata O. F. Müll., Lymnaea peregra (O. F. Müll.), Anisus contortus (L.), Gyraulus albus (O. F. Müll.), G. laevis (Ald.), Pisidium milium Held) are frequent as well (Fig. $3 \mathrm{M}$, Table 1).

The two-component diagram D-1 reflects processes of formation, development and finally drainage of the pond. The phase of its maximum extent is evidenced in the middle part of diagram D-2. The last diagram (D-3) indicates the absence of molluscs typical of rivers or streams (Fig. 3 D).

Profile Kt-IV is situated near the dam (Fig. 1). Seven samples (Kt-20 - Kt-26) (Fig. $3 \mathrm{Sa}$ ) contained an assemblage dominated by aquatic species. The number of taxa in particular samples varies between 10 and 31, and the number of specimens ranges from 53 to 884 (Fig. $3 \mathrm{~N}$ ). Open-country (Vallonia pulchella (O. F. Müll.), Pupilla muscorum (L.)), catholic (Carychium tridentatum (Risso), Succinea oblonga Drap. and higrophile (Carychium minimum O. F. Müll., Succinea putris (L.)) land snails are numerous only in the uppermost part of the profile (Fig. $3 \mathrm{M}$ ). Water molluscs are represented by species typical of tempo- rary water bodies (Lymnaea truncatula (O. F. Müll.), Anisus leucostomus (Mill.), Valvata pulchella Studer) as well as taxa inhabiting permanent waters with rich vegetation: Valvata cristata O. F. Müll., Bithynia tentaculata (L.), Lymnaea peregra (O. F. Müll.), Anisus contortus (L.), Gyraulus albus (O. F. Müll.), G. laevis (Ald.), Pisidium milium Held (Fig. $3 \mathrm{M}$ ).

The two-component diagram D-1 illustrates the evolution of the pond. The dominance of land snails in the upper part of the sequence indicates the transformation of the water body into a swamp, and finally into a wet meadow. The mid part of diagram D-2 corresponds with the maximum extent of the pond. The influence of the stream was very limited (D-3) (Fig. 3 D).

Succession of mollusc assemblages in particular profiles is presented in triangular diagrams, including three components of the assemblages: land snails (ecological groups 1-8), species typical for swamps, marshes and temporary water bodies (ecological groups 9,10) and molluscs inhabiting permanent basins of stagnant water and rivers or streams (ecological groups 11, 12) (Fig. 4). Two main types of succession can be distinguished. The first is represented in profiles Kt-I and Kt-II, associated with the marginal zone of the pond. The samples of the mentioned profiles represent polymictic fauna. The considerable proportion of land snails is characteristic of these assem- 

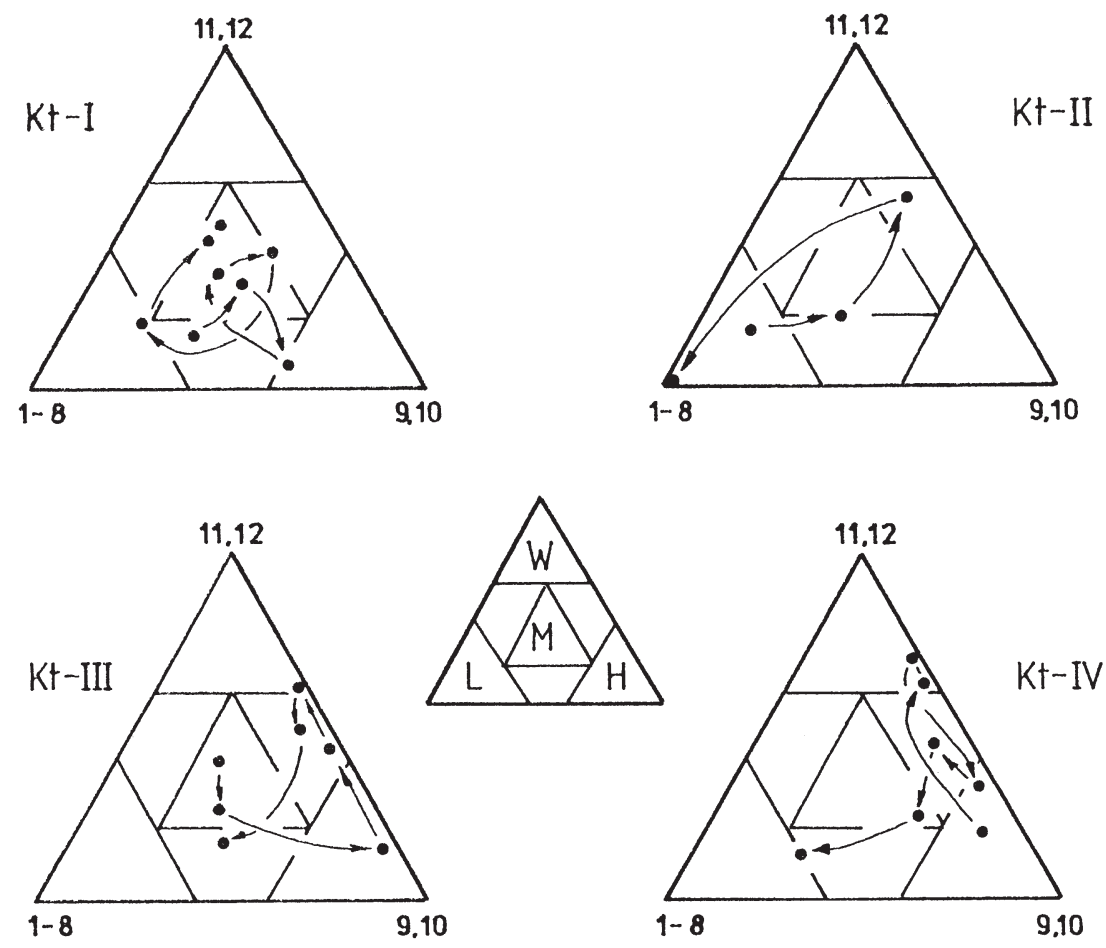

Fig. 4. Succession of mollusc assemblages in profiles from Korytnica: W - water molluscs, L - land snails, H - higrophile taxa. For explanation of ecological groups see Fig. 2 and Table 1

blages which developed under the influence of the stream and adjacent slopes (Fig. 4). The second type of mollusc succession (profiles Kt-III and Kt-IV) reflects the development of the pond. In its lowermost part there occur assemblages containing both

\section{CONCLUSIONS}

The sequences of sediments and the succession of mollusc assemblages from Korytnica reflect the evolution of the small valley, controlled mainly by human activity. Three types of sediments containing different molluscan assemblages can be distinguished.

The first type is associated with sedimentation controlled by fluviatile processes. The intercalations of sand and mud with fragments of Cretaceous marls in profile Kt-I, as well as sandy layers in the lower part of profiles Kt-II and Kt-III point to this phase. The mollusc fauna is composed mainly of land snails with a limited proportion of water molluscs. Open-country and mesophile taxa, such as Vallonia pulchella (O. F. Müll.), V. costata (O. F. Müll.), Pupilla muscorum (L.), Cochlicopa lubrica (O. F. Müll.), Carychium tridentatum (Risso) and some others, dominate. Woodland snails: Acicula polita (Hartm.), Ruthenica filograna (Rossm.), Bradybaena fruticum (O. F. Müll.), Discus rotundatus (O. F. Müll.) have been found as well. There is a significant admixture of higrophile species living both in open (Carychium minimum O. F. Müll., Succinea putris higrophile terrestrial and water molluscs. They are replaced by an assemblage dominated by aquatic species and finally by a fauna with a significant admixture of open-country and mesophile taxa (Fig. 4).

(L.)) and in more shady habitats (Perforatella bidentata (Gmel.)). Molluscs typical for temporary water bodies - Lymnaea truncatula (O. F. Müll.), Anisus leucostomus (Mill.), as well as bivalves inhabiting streams (Pisidium personatum Malm) supplement the described community. The presented assemblage indicates open or partly wooded habitats of a small and relatively wide valley. Similar assemblages were described from numerous localities of the Cracow Upland (S. W. AlEXANDROWICZ 1984, 1987b, 1988, 1992, 1997) and the Carpathians (S. W. AlEXANDrOWICZ 1990, 1993a, W. P. AlEXANDROWICZ 1991, 1997, S. W. AlEXANDROWICZ \& W. P. ALEXANDROWICZ 1995).

The second stage of evolution of the mentioned valley is associated with building the dam and development of the fish pond, i.e. since the first half of the 19th c. till the final drainage during World War II. The sequence of mud deposits from profiles Kt-III and $\mathrm{Kt}-\mathrm{IV}$, middle of the profile Kt-II, as well as intercalations of mud in profile Kt-I, accumulated in this pond. The deposits contain a rich mollusc assemblage domi- 
nated by water species of shallow, temporary water bodies, such as Lymnaea truncatula (O. F. Müll.), Anisus leucostomus (Mill.), as well as molluscs inhabiting permanent stagnant water bodies with rich vegetation (Valvata cristata O. F. Müll., Bithynia tentaculata (L.), Anisus contortus (L.), Gyraulus laevis (Ald.), G. albus (O. F. Müll.) etc.). Land snails and rheophile taxa are subordinate components of this assemblage. The fauna described above indicates the development of a small, permanent stagnant water body with a rich vegetation. Water level fluctuations are well reflected in profile Kt-I situated in the marginal part of the pond. Two periods of the maximum extent of the water body are separated by sand associated with fluviatile accumulation. The progressive overgrowing with vegetation as well as filling with sediments were the main factors controlling the development of the pond. Similar mollusc assemblages were described from small dammed lakes influenced by landslides in the Carpathians (S. W. ALEXANDROWICZ 1985, 1993b, 1996a).

The third phase of development of the studied area is connected with the last fifty years. In all the profiles mud accumulated in the pond is overlain by recent soil with a considerable content of sand. It developed after filling and drainage of the pond. Mollusc assemblages occurring in the uppermost part of the profiles are dominated by open-country snails (Vallonia pulchella (O. F. Müll.), V. costata (O. F. Müll.)

\section{REFERENCES}

ALEXANDROWICZ S. W. 1984. Late Quaternary molluscan successions of the Małopolska Upland. Bull. Pol. Acad. Sci., Earth Sci. 32: 27-36.

ALEXANDROWICZ S. W. 1985. Subfosylna malakofauna z osuwiska w Piwnicznej. Folia Quatern. 56: 79-100.

AleXANDROWICZ S. W. 1987a. Analiza malakologiczna w badaniach czwartorzędowych. Kwart. AGH, Geologia 12: 3-240.

AleXANDrowicz S. W. 1987b. Malakofauna późnego vistulianu i holocenu środkowej części Wyżyny Małopolskiej. Prace Nauk. UO. 712: 25-56.

AlEXANDROWICZ S. W. 1988. The stratigraphy and malacofauna of the Holocene sediments of the Prądnik River Valley. Bull. Pol. Acad. Sci., Earth Sci. 36: 109-120.

ALEXANDROWICZ S. W. 1990. The malacofauna of Late Holocene sediments of Sromowce (the Pieniny Mountains, Southern Poland). Folia Malacol. 4: 7-24.

ALEXANDrowicz S. W. 1992. Malakofauna i zmiany środowiska południowej Polski w holocenie. Kwart. AGH, Geologia 18: 5-35.

AleXANDrowicz S. W. 1993a. Late Holocene molluscan assemblages from Czorsztyn (Pieniny Klippen Belt, Southern Poland). Folia Malacol. 5: 15-24.

ALEXANDROWICZ S. W. 1993b. Late Quaternary landslides at eastern periphery of the National Park of the Pieniny and mesophile taxa preferring relatively humid habitats (Carychium tridentatum (Risso), Vertigo angustior Jeffr.). Higrophile species (Succinea putris (L.), Carychium minimum O. F. Müll., Vertigo antivertigo (Drap.) ) have been found as well. Molluscs of temporary water bodies (Lymnaea truncatula (O. F. Müll.), Anisus leucostomus (Mill.)) complete this assemblage. The presence of snails living in cultivated areas (Cecilioides acicula (O. F. Müll.)) as well as xerophile species (Helicopsis striata (O. F. Müll.), Truncatellina costulata (Nilss.)) is a characteristic feature of this assemblage and indicates open habitat partly controlled by human activity. Similar communities were described from the Cracow Upland (S. W. AlEXANDROWICZ 1987b, 1996b, S. W. ALEXANDROWICZ et al. 1997).

Deposits containing mollusc assemblages described above are associated with the last two hundred years. The succession of the fauna indicates changes of the environment on the bottom of a small valley, controlled by fluviatile processes and human activity: construction of a dam, formation of a fish-pond gradually filled with sediments, and finally its drainage.

\section{ACKNOWLEDGEMENTS}

The study is a contribution to scientific project no 11.11.140.51. sponsored by the Academy of Mining and Metallurgy in Cracow.

Mountains, Carpathians, Poland. Stud. Geol. Pol. 102: 209-225.

ALEXANDROWICZ S. W. 1996a. Holoceńskie fazy intensyfikacji procesów osuwiskowych w Karpatach. Kwart. AGH, Geologia 22: 223-262.

AleXANDrowicz S. W. 1996b. Malacofauna of Late Holocene overbank deposits in Southern Poland. Bull. Pol. Acad. Sci., Earth Sci. 44: 235-249.

ALEXANDROWICZ S. W. 1997. Malcofauna of Holocene sediments of the Prądnik and Rudawa River Valleys. Folia Quatern. 68: 133-188.

ALEXANDrowicz S. W., ALEXANDrowicz W. P. 1995. Quaternary molluscan assemblages of the Polish Carpathians. Stud. Geomorph. Carpatho.-Balc. 29: 41-54.

AleXAndrowicz S. W., AleXANDrowicz W. P., Krąiec M., SZYCHOWSKA-KRĄPIEC E. 1997. Zmiany środowiska południowej Polski w okresie historycznym. Kwart. AGH, Geologia 23: 339-387.

ALEXANDROWICZ W. P. 1991. Zespół mięczaków w madach historycznych Kotliny Żywieckiej. Spraw. Pos. Kom. Nauk. PAN, Oddz. Kraków 33: 226-227.

ALEXANDROWICZ W. P. 1997. Malakofauna osadów czwartorzędowych i zmiany środowiska naturalnego Podhala w młodszym holocenie. Folia Quatern. 68: 7-132.

BAŁUK W., RADWAŃSKI A. 1977. Organic communities and facies development of the Korytnica Basin (Middle Mio- 
cene; Holy Cross Mountains, Central Poland). Acta Geol. Pol. 27: 85-123.

Kutek J., GŁAZEK J. 1972. The Holy Cross area, Central Poland, in the Alpine cycle. Acta Geol. Pol. 22: 603-653.

LINDNER L. 1977. Pleistocene glaciations in the western part of the Holy Cross Mountains (Central Poland). Stud. Geol. Pol. 53: 1-123.

LOŽEK V. 1964. Quartarmollusken der Tschechoslowakei. Rozpr. UUG. 31: 3-374.

PIECHOCKI A. 1979. Mięczaki (Mollusca) - Ślimaki (Gastropoda). Fauna Słodkowodna Polski 7, PWN, Warszawa.

Piechocki A., Dyduch-FALNIOWSKA A. 1993. Mięczaki ( Mollusca) - Małże (Bivalvia). Fauna Słodkowodna Polski 7A, PWN, Warszawa.
RADWAŃSKI A. 1969. Lower Tortonian transgression onto the southern slopes of the Holy Cross Mountains. Acta Geol. Pol. 19: 1-164.

RADWAŃSKI A. 1973. Lower Tortonian transgression onto the south-eastern and eastern slopes of the Holy Cross Mts. Acta Geol. Pol. 23: 375-434.

RIEDEL A. 1988. Ślimaki lądowe (Gastropoda terrestria). Katalog fauny Polski 36, PWN, Warszawa.

received: April 15th, 2001 accepted: May 29th, 2001 